\section{Nitrogen Accumulation and Loss in a High-input Greenhouse Vegetable Cropping System Elevated by Application of Manures}

\section{Zhi Quan}

Key Laboratory of Pollution Ecology and Environmental Engineering, Institute of Applied Ecology, Chinese Academy of Sciences, Shenyang 110016, People's Republic of China; and State Key Laboratory of Forest and Soil Ecology, Institute of Applied Ecology, Chinese Academy of Sciences, Shenyang 110164, People's Republic of China

\section{Bin Huang, Caiyan Lu' ${ }^{1}$, Yi Shi, Yanhong Cao, Yongzhuang Wang, Chuanrui He, Guangyu Chi, Jian Ma, and Xin Chen \\ Key Laboratory of Pollution Ecology and Environmental Engineering, Institute of Applied Ecology, Chinese Academy of Sciences, Shenyang 110016, People's Republic of China}

Additional index words. distribution, migration, soluble organic nitrogen, acidification, $\mathrm{pH}$, EC

\begin{abstract}
Much nitrogen (N) is lost in high-input protected cropping systems mainly via leaching of not only nitrate-N but also extractable organic $N$ (EON), but the role of EON in this process is poorly appreciated. A consecutive 3-year plot experiment was conducted to investigate the impact of co-application of manures with chemical $\mathbf{N}$ fertilizer on $\mathbf{N}$ accumulation and loss in a greenhouse soil rotationally planted with cucumber or tomato and lettuce. Application of manures significantly enhanced the average contents and stocks of $\mathrm{NO}_{3}{ }^{-}-\mathrm{N}$, EON, and total $\mathrm{N}$ (TN) in 0 - to $60-\mathrm{cm}$ soil layer, although EON accumulated within growing season, while $\mathrm{NO}_{3}{ }^{-}-\mathrm{N}$ accumulated with fluctuation, and TN accumulated gradually throughout the 3-year experiment. With application rate at 120 or $180 \mathrm{t}$ dry manures per hectare per 3 years, the corresponding apparent $\mathrm{N}$ surplus was 2710 or $3924 \mathrm{~kg} \cdot \mathrm{ha}^{-1}$ per 3 years. Due to little increase of biomass $\mathrm{N}$ uptakes during vegetable seasons, the accumulated $N$ in soil profile would be a potential loss source, largely via leaching of both nitrate and EON. Application of manures slowed soil acidification but intensified secondary salinization of the greenhouse soil. Considering the manures-induced high soil $\mathbf{N}$ accumulation and loss, well-balanced evaluation of the role of manures in high-input agricultural ecosystems is needed.
\end{abstract}

Nitrogen is an essential nutrient for plant growth. Nitrogen fertilization is the major feature of intensive agricultural management to improve crop yields (Zhao et al., 2014; Zhu and Chen, 2002). Generally, manures are applied together with chemical $\mathrm{N}$ fertilizer to buffer soil acidification, improve microbial activity and functional diversity, provide nutrients, and maintain the sustainable productivity (Hati et al., 2008; Shen et al., 2010; Zhao et al., 2012). The relatively low cost of manures and the increasing demand for cheap food have encouraged the overuse and misuse of manures in the last several decades

\footnotetext{
Received for publication 23 July 2015. Accepted for publication 2 Sept. 2015.

This research was supported by grant from the National Natural Science Foundation of China (grant number 41001176) and Liaoning Science and Technology Project Program (grant number 2011215003; 2014215016).

${ }^{1}$ Corresponding author. E-mail: microyan76@ 126.com.
}

(Tian et al., 2011), resulting in the accumulation of superfluous $\mathrm{N}$ in soil (Fan et al., 2010; Zhao et al., 2014), and its migration to a deeper soil layer or groundwater when the conditions are satisfied (Bergström and Kirchmann, 1999).

High-input cropping systems, especially greenhouse cultivation, develop quickly in China to meet consumer demand for vegetables throughout the whole year (Qiu et al., 2010; Yan et al., 2012). However, closed growth environment and high-rate fertilization easily degrade a greenhouse soil within a period of several years (Lei et al., 2010). Co-application of organic fertilizers such as manures with chemical fertilizers may alleviate the deterioration of soil quality but maintain high yield. However, application of manure N, typically in the range of 1000 $3046 \mathrm{~kg} \mathrm{~N} / \mathrm{ha} /$ year (Ju et al., 2007; Shi et al., 2008; Thompson et al., 2007) and accounting for $51 \%$ to $65 \%$ of $\mathrm{TN}$ inputs in greenhouse vegetable cultivation systems (Gao et al., 2012; Ju et al., 2006), increases the overall rate of $\mathrm{N}$ fertilization, making greenhouse cropping systems accumulate superfluous $\mathrm{N}$ subject to loss via denitrification and leaching. The averaged $\mathrm{N}$ surplus in 0 - to $90-\mathrm{cm}$ soil layer was up to $3327 \mathrm{~kg} \mathrm{~N} / \mathrm{ha} /$ year in vegetable cultivation greenhouses $(n=56)$ in Huiming, North China (Ju et al., 2006). Nitrate as the main form of mobile $\mathrm{N}$ in greenhouse soil highly accumulate and easily migrate to shallow aquifers causing very serious nitrate pollution in nearby shallow wells (Ju et al., 2006). The extent of nitrate pollution in soil and shallow aquifers will continue to be worsened when greenhouse cultivation continue (Zhang et al., 2010).

Available evaluations on $\mathrm{N}$ leaching risk in greenhouse soils are mainly based on accumulation and migration of nitrate in soil profile (Ju et al., 2006; Zhang et al., 2010), while the leaching loss via other forms of leachable $\mathrm{N}$ is not well appreciated. Other forms of leachable N, especially EON, have been suggested to be taken into account when evaluating $\mathrm{N}$ leaching risk due to its large contribution to $\mathrm{N}$ migration in the soil profile (Bhogal et al., 2000; Khalili and Nourbakhsh, 2012; Siemens and Kaupenjohann, 2002). Especially in greenhouse soils, often-applied manures may be a direct source of EON subject to leaching loss (Goyne et al., 2008). Hence, simultaneous investigation of accumulation and migration of nitrate and $\mathrm{EON}$ is needed to better understand the scale and the dynamics of $\mathrm{N}$ migration and leaching loss in greenhouse soils. In this study, a 3-year experiment was conducted in greenhouse soil rotationally planted with cucumber or tomato and lettuce with and without manures to investigate the spatial (vertical) and temporal dynamics of nitrate, EON, and TN in soil, and estimate the leaching-dominated $\mathrm{N}$ loss based on $\mathrm{N}$ balance in soil.

\section{Materials and Methods}

Site description. A long-term microplot experiment was conducted in a traditional solar greenhouse $\left(41^{\circ} 31^{\prime} \mathrm{N}, 123^{\circ} 22^{\prime} \mathrm{E}\right)$ near Shenyang city from Dec. 2010 (Quan et al., 2014). From 2006 to 2010 , this field was used to cultivate vegetables by conventional practices, and theretofore it was a corn field. The soil in the field is meadow burozem (Inceptisols in U.S. soil taxonomy). Soil basic properties are listed in Table 1.

Rotation of two vegetables in 1 year was arranged in the microplots $\left(3.4 \times 3.8 \mathrm{~m}^{2}\right)$ : September to December for lettuce (Lactuca sativa L.) season, and January to June for cucumber (Cucumis sativus L.) or tomato (Lycopersicon esculentum Mill.) season. There were summer fallows $(\approx 3$ months) and winter fallows $(\approx 20 \mathrm{~d})$ between the two consecutive vegetable production seasons.

Experimental design. Three treatments were set up according to the application rate of manure (dry basis): no manure (Control), $20 \mathrm{t} \cdot \mathrm{ha}^{-1}$ per season (M 20), and $30 \mathrm{t} \cdot \mathrm{ha}^{-1}$ per season (M 30, local normal rate). Each treatment had three replications. The normal application rate that farmers chose was based on the need of organic matter in soil to 
improve soil properties and provide nutrients for plants. The experimental microplots $(3 \times 3)$ were arranged as randomized block design in the central area of the greenhouse. Manures were broadcasted to the fields as basal dressing evenly after composting and drying (chicken manure for cucumber or tomato season, and cattle manure for lettuce season). Carbon (C) and $\mathrm{N}$ contents of the manures are listed in Table 2. Compound chemical fertilizer $\left(\mathrm{N}: \mathrm{P}_{2} \mathrm{O}_{5}: \mathrm{K}_{2} \mathrm{O}=15: 15: 15\right)$ was broadcasted at $1 \mathrm{t} \cdot \mathrm{ha}^{-1}$. Tillage was thereafter done using a small plough $(0-20 \mathrm{~cm})$ and vegetable seedlings were transplanted at densities of 110,72 , and 72 plants/plot for lettuce, cucumber, and tomato, respectively. Amino acid liquid fertilizer was applied to the root area to facilitate the survival of seedlings after transplanting.

During the six consecutive vegetable seasons, irrigation was carried out regularly in the furrows (Fig. 1). Irrigation water was pumped from a well near the greenhouse, and the irrigation rate was $\approx 730 \mathrm{~mm}$ annually (TN in irrigated water $<3 \mathrm{mg} \cdot \mathrm{L}^{-1}$ ). No rain water enters the greenhouse owing to the plastic film covering all year-round. All aboveground vegetable residues were moved out of the greenhouse after harvest. Nitrogen inputs in the system from the studied period

Soil sampling. Background soil was sampled on 20 Dec. 2010. Soil samples of the six vegetable growth periods (four in cucumber/ tomato season, and two in lettuce season) were taken at the depths of $0-10,10-20,20$ 40 , and $40-60 \mathrm{~cm}$ with a $2.5-\mathrm{cm}$-diameter soil drill. Soil samples were taken almost 1 week after irrigation to weaken the impact from irrigation except for the background soil samples. Six soil cores were taken from each

Table 1. Soil physical and chemical properties of topsoil $(0-20 \mathrm{~cm})$ before the 3-year plot experiment start.

\begin{tabular}{lccl}
\hline Characteristic & $0-10 \mathrm{~cm} 10-20 \mathrm{~cm}$ & Units \\
\hline Soil type & \multicolumn{3}{c}{ Silty loam } \\
pH & 6.43 & 6.64 & \\
EC & 483 & 241 & $\mu \mathrm{s} \cdot \mathrm{cm}^{-1}$ \\
Bulk density & 1.12 & 1.27 & $\mathrm{~g} \cdot \mathrm{cm}^{-3}$ \\
Total C & 1.38 & 1.12 & $\mathrm{~g} \cdot \mathrm{kg}^{-1}$ \\
Total N & 1.28 & 0.94 & $\mathrm{~g} \cdot \mathrm{kg}^{-1}$ \\
Total C/total N & 10.8 & 11.9 & \\
Extractable $\mathrm{NO}_{3}{ }^{-}-\mathrm{N}$ & 46.9 & 19.9 & $\mathrm{mg} \cdot \mathrm{kg}^{-1}$ \\
Extractable $\mathrm{NH}_{4}^{+}-\mathrm{N}$ & 25.1 & 15.7 & $\mathrm{mg} \cdot \mathrm{kg}^{-1}$ \\
Extractable organic N & 12.8 & 17.8 & $\mathrm{mg} \cdot \mathrm{kg}^{-1}$ \\
Total P & 0.22 & 0.14 & $\mathrm{~g} \cdot \mathrm{kg}^{-1}$ \\
Total K & 16.5 & 15.7 & $\mathrm{~g} \cdot \mathrm{kg}^{-1}$ \\
\hline
\end{tabular}
of 2011 to 2013 are listed in Table 3.

plot to make a composite sample. After removal of stones, visual fauna, and plant residues, fresh soil samples were mixed homogeneously and sieved $(<2 \mathrm{~mm})$. Subsamples were stored at $-18{ }^{\circ} \mathrm{C}$ in the refrigerator for $\mathrm{NH}_{4}{ }^{+}-\mathrm{N}, \mathrm{NO}_{3}{ }^{-}-\mathrm{N}$, and total extractable $\mathrm{N}$ (TEN) analysis. The rest samples were airdried, ground, and sieved $(<0.15) \mathrm{mm}$ for $\mathrm{TN}$ analysis.

Plant sampling. Fruit samples (cucumbers and tomatoes) were collected from the beginning of fruiting to the end of vegetable growing season. Six aboveground plant samples from each plot, partitioned into stems and leaves, were sampled at the end of vegetable growing seasons. Aboveground biomass (stems and leaves) and fresh vegetable yield were recorded when samples were taken. Subsamples were oven-dried at $70{ }^{\circ} \mathrm{C}$ for $48 \mathrm{~h}$ to calculate dry weight and plant $\mathrm{N}$ absorption.

Sample analysis. Field-moist soil samples of $20 \mathrm{~g}$ were weighed and extracted by shaking with $100 \mathrm{~mL}, 2 \mathrm{~mol} \cdot \mathrm{L}^{-1} \mathrm{KCl}$ for $1 \mathrm{~h}$. Extractable $\mathrm{NO}_{3}{ }^{-}-\mathrm{N}$ and $\mathrm{NH}_{4}{ }^{+}-\mathrm{N}$ in extracts were determined by continuous flow analyzer (AA3; Seal, UK). Total extractable $\mathrm{N}$ in extracts was determined by TOC-TN analyzer (Multi N/C 3100; Analytik Jena, Germany) (extracts pass through $0.45-\mu \mathrm{m}$ filter membrane before injection). Extractable organic $\mathrm{N}=\mathrm{TEN}-$ $\mathrm{NO}_{3}{ }^{-}-\mathrm{N}-\mathrm{NH}_{4}{ }^{+}-\mathrm{N}$. The extracts were kept in polypropylene bottles in $\mathrm{a}-18{ }^{\circ} \mathrm{C}$ refrigerator before analysis.

Soil and manure $\mathrm{pH}(1: 2.5, \mathrm{w} / \mathrm{v})$ and electrical conductivity (EC) $(1: 5, \mathrm{w} / \mathrm{v})$ were determined separately by a $\mathrm{pH}$ electrode (Model 868; Thermo Electron, China) and an electrical conductivity meter (DDSJ-308A; Leici, China) to evaluate acid and salt accumulation. Soil, plant, and manure total C, TN, total phosphorus, and total potassium were determined by combustion, Kjeldahl, molybdenum, and flame photometer methods.

Soil $N$ loss estimation. The estimated soil $\mathrm{N}$ loss was calculated by the following formula:

$$
\begin{aligned}
& \text { Nitrogen loss }=\text { input } \mathrm{N} \text { components } \\
& \text { (compound fertilizer }+ \text { manure } \\
& + \text { irrigation }+ \text { transplanting } \\
& + \text { liquid amino acid fertilizer }+ \text { pesticide }) \\
& \text { - output } \mathrm{N} \text { components } \\
& \text { (N removed by aboveground plant parts }) \\
& \text { - change of soil TN stock }(\Delta \mathrm{TN})
\end{aligned}
$$

The $\mathrm{N}$ loss represented $\mathrm{N}$ that was lost via nitrogenous gas (ammonia volatilization,

Table 2. Carbon and nitrogen contents of chicken and cattle manures.

\begin{tabular}{lcccccccc}
\hline & $\mathrm{Yr}$ & $\begin{array}{c}\mathrm{TOC}^{\mathrm{z}} \\
\left(\mathrm{g} \cdot \mathrm{kg}^{-1}\right)\end{array}$ & $\begin{array}{c}\mathrm{TN} \\
\left(\mathrm{g} \cdot \mathrm{kg}^{-1}\right)\end{array}$ & $\begin{array}{c}\mathrm{NO}_{3}{ }^{-\mathrm{N}} \\
\left(\mathrm{g} \cdot \mathrm{kg}^{-1}\right)\end{array}$ & $\begin{array}{c}\mathrm{NH}_{4}{ }^{+}-\mathrm{N} \\
\left(\mathrm{g} \cdot \mathrm{kg}^{-1}\right)\end{array}$ & $\begin{array}{c}\mathrm{EON} \\
\left(\mathrm{g} \cdot \mathrm{kg}^{-1}\right)\end{array}$ & $\begin{array}{c}\mathrm{TEN} \\
\left(\mathrm{g} \cdot \mathrm{kg}^{-1}\right)\end{array}$ & $\mathrm{pH}$ \\
\hline Chicken manure & 2011 & 100 & 18.8 & $<0.01$ & 2.01 & 3.55 & 5.56 & 7.35 \\
& 2012 & 96 & 17.7 & 0.38 & 1.48 & 2.28 & 4.14 & 7.18 \\
Cattle manure & 2013 & 261 & 31.9 & $<0.01$ & 2.08 & 6.02 & 8.10 & 6.86 \\
& 2011 & 235 & 18.5 & 1.27 & 0.04 & 0.20 & 1.51 & 7.83 \\
& 2012 & 218 & 19.2 & 0.81 & 0.02 & 0.15 & 0.98 & 7.77 \\
& 2013 & 252 & 20.0 & 1.05 & 0.02 & 0.05 & 1.12 & 7.42 \\
\hline
\end{tabular}

${ }^{\mathrm{z}} \mathrm{TOC}=$ total organic carbon; $\mathrm{TN}=$ total nitrogen; $\mathrm{EON}=$ extractable organic nitrogen; $\mathrm{TEN}=$ total extractable nitrogen $\left(\mathrm{TEN}=\mathrm{NO}_{3}{ }^{-} \mathrm{N}+\mathrm{NH}_{4}{ }^{+}-\mathrm{N}+\mathrm{EON}\right)$ extracted by distilled water (v/w, 20:1). nitrification, or denitrification) and nitrogenous solution (leaching or runoff). Nitrogen inputs from compound fertilizer, manures, and amino acid fertilizer were calculated from fertilization rates during the 3-year experiment. Nitrogen inputs from irrigation and transplanting were estimated by the average concentrations of obtaining samples and the total application rate to each treatment. Nitrogen inputs from dry deposition and pesticides were considered to be negligible because of the close system in the greenhouse and the low-rate application of pesticides (Table 3). Nitrogen outputs in aboveground plant parts were calculated from the $\mathrm{N}$ concentration in each harvested component of the plant samples and the ovendry yield, and added up for each field. Change of soil TN stock $(\Delta T N)$ was based on the 3 -year change of stocks of soil TN in 0 - to $60-\mathrm{cm}$ soil layer. The stock $\left(\mathrm{kg} \cdot \mathrm{ha}^{-1}\right)$ of each form of $\mathrm{N}\left(\mathrm{NO}_{3}{ }^{-}-\mathrm{N}, \mathrm{NH}_{4}{ }^{+}-\mathrm{N}, \mathrm{EON}\right.$, and $\left.\mathrm{TN}\right)$ was calculated using the formula below:

$$
\begin{aligned}
\text { Stocks } & =\sum_{i=1}^{4} \text { concentration }_{i}\left(\mathrm{mg} \cdot \mathrm{kg}^{-1}\right) \\
& \times \text { bulk densities }_{i}\left(\mathrm{~g} \cdot \mathrm{cm}^{-3}\right) \\
& \times \text { volume }_{i}\left(\mathrm{~m}^{3} \cdot \mathrm{ha}^{-1}\right) \times 10^{-3}
\end{aligned}
$$

where " $i$ " is the soil layer $(i=1-4$ for $0-10$, $10-20,20-40$, and $40-60 \mathrm{~cm}$ ), and values of $1.12,1.27,1.44$, and $1.43 \mathrm{~g} \cdot \mathrm{cm}^{-3}$ are the bulk densities of $0-10,10-20,20-40$, and 40-60 cm soil layers, respectively.

Statistical analysis. Soil data were expressed on oven-dried soil basis. Oneway analysis of variance (ANOVA) was performed to compare the results among the treatments using SPSS 16.0 software (SPSS Inc., Chicago, IL). Means were compared using least significant difference test at the 0.05 level if the results were significant. Three-way ANOVAs were performed for the individual and interactive effects of manures, depth, and year on $\mathrm{NO}_{3}{ }^{-}-\mathrm{N}, \mathrm{NH}_{4}{ }^{+}-\mathrm{N}$, EON, and TN. Standard errors were selected to represent the error bars in figures.

\section{Results}

$N$ inputs in greenhouse soil. Total $\mathrm{N}$ inputs in the greenhouse soil during the 3 -year vegetables cultivation were 1653 , 4069, and $5277 \mathrm{~kg} \mathrm{~N} / \mathrm{ha}$ for Control, M 20, and M 30 treatments, respectively (Table 3). Manure N (chicken and cattle manures) took the biggest part in TN input for M 20 and M 30 treatments (59.4\% and $68.7 \%$, respectively). Partitioning the TN input into three parts (Fig. 2), nonextractable $\mathrm{N}$ had the highest differences among the three treatments, followed by EON, and the differences in EIN input were smallest among the treatments.

Aboveground biomass and biomass $N$ uptake. The summed aboveground fresh biomass and biomass $\mathrm{N}$ uptake did not significantly respond to the application of manures (Table 4). There were no statistical differences in aboveground biomass or biomass $\mathrm{N}$ uptake $(P>0.05)$ among Control and the two manures-applied treatments during most of 
vegetable seasons, apart from a few exceptions (during cucumber season in 2012 and lettuce seasons in 2012 and 2013, manures application treatments were significant higher than Control treatment).

Vertical and temporal variation of $\mathrm{NO}_{3}{ }^{-}-\mathrm{N}$, $\mathrm{NH}_{4}^{+}-\mathrm{N}, \mathrm{EON}$, and $\mathrm{TN}$. Average concentrations of $\mathrm{NO}_{3}{ }^{-}-\mathrm{N}, \mathrm{NH}_{4}{ }^{+}-\mathrm{N}$, and $\mathrm{EON}$ in 0 - to $60-\mathrm{cm}$ soil layer accounted for $59.8 \%$ to $82.2 \%, 3.6 \%$ to $10.4 \%$, and $12.5 \%$ to $30.9 \%$ of TEN, respectively (Table 5). The average ratio of TEN:TN varied from $4.6 \%$ to $10.6 \%$ in a decrease trend with the increase of soil depth, and followed an order of M $30>$ M $20>$ Control. Compared with Control, manures enhanced the averaged TN concentrations by $27.9 \%$ (M 20), 51.4\% (M 30) in 0- to $10-\mathrm{cm}$ soil layer and 27.0\% (M 20), 28.1\% (M 30) in 10- to 20-cm soil layer.

Based on the results of three-way ANOVAs, besides soil layer and application of manures, sampling period also profoundly affected soil extractable $\mathrm{N}$ and $\mathrm{TN}$ variations in the greenhouse soil cultivated with vegetables $(P<0.01)$.

Soil EON and $\mathrm{NH}_{4}^{+}-\mathrm{N}$ stocks peaked in the middle of vegetable growth periods and backed to low levels at the end of the each vegetable growing season, showing an obvious seasonal variation (Fig. 3). After the 3 -year experiment, no significant increase in
EON or $\mathrm{NH}_{4}^{+}-\mathrm{N}$ stock was observed among Control, M 20, and M 30 treatments, whereas $\mathrm{NO}_{3}{ }^{-} \mathrm{N}$ stocks increased by $2.0,5.5$, and 5.4 times, respectively, and TN stock decreased in Control treatment but increased in M 20 and M 30 treatments.

Nitrogen loss. The $\mathrm{N}$ uptake proportion ( $\mathrm{N}$ in aboveground biomass/TN input) decreased from $76.1 \%$ to $25.6 \%$ with increasing the application rate of manures from 0 to 30 t.ha ${ }^{-1}$ (Table 6). The apparent $\mathrm{N}$ surpluses were 394,2710 , and $3924 \mathrm{~kg} \cdot \mathrm{ha}^{-1}$ per 3 years for Control, M 20, and M 30 treatments, respectively. Nitrogen accumulation (soil $\Delta \mathrm{TN}$ ) varied highly across the treatments, accounting for $-4.9 \%, 37.6 \%$, and $41.2 \%$ of input $\mathrm{N}$ for Control, M 20, and M 30 treatments, respectively. The two manures-applied treatments resulted in high amounts of $\mathrm{N}$ loss out of 0 - to $60-\mathrm{cm}$ soil profile, consequently reducing the $\mathrm{N}$ use efficiencies.

Soil acidification and salinization. After the 3-year experiment, application of manures slowed the soil acidification markedly but accelerated soil salinization (Fig. 4). Fertilization and high-intensity cultivation decreased the $\mathrm{pH}$ of the greenhouse soil by units of $1.11,0.36$, and $0.29(0-10 \mathrm{~cm})$, but increased the EC by $1.18,0.58$, and $1.73(0-10 \mathrm{~cm})$ times for the Control, M 20, and M 30 treatments, respectively.

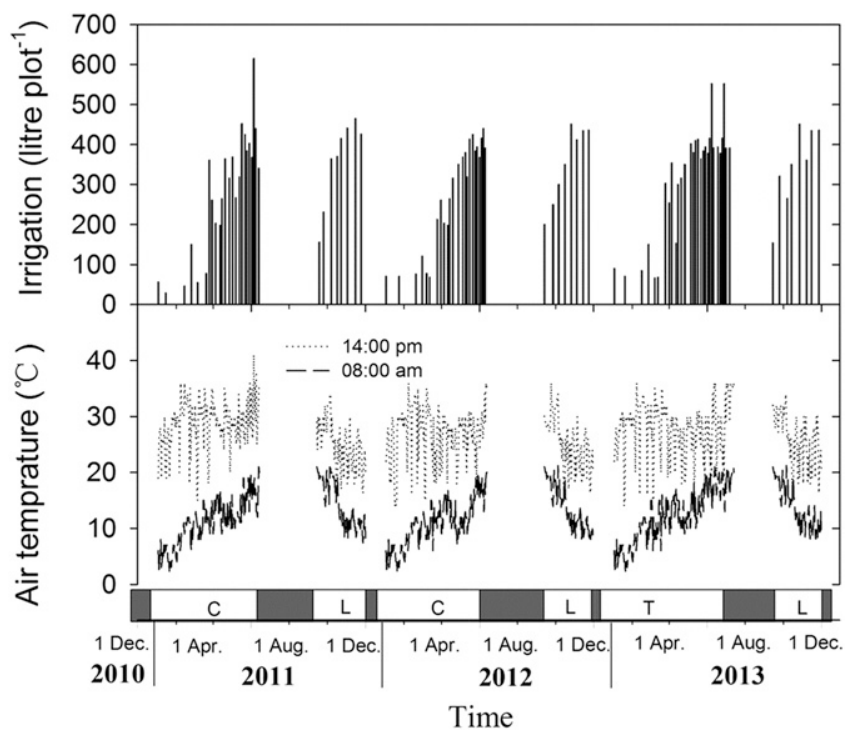

Fig. 1. Irrigation events and air temperatures (1 m aboveground, 08:00 AM and 14:00 PM) throughout the vegetable growing seasons. Abbreviations "C," "L," and "T" indicate "cucumber," "lettuce," and "tomato" seasons. Darkness refers to the summer or winter fallow periods.

\section{Discussion}

Extractable $\mathrm{N}$ speciation $\left(\mathrm{NO}_{3}^{-}-\mathrm{N}, \mathrm{EON}\right.$, $\left.\mathrm{NH}_{4}^{+}-\mathrm{N}\right)$. Accumulation of extractable $\mathrm{N}$ components across the three treatments followed the order of $\mathrm{NO}_{3}{ }^{-}-\mathrm{N}>\mathrm{EON}>\mathrm{NH}_{4}{ }^{+}-\mathrm{N}$. Although $\mathrm{NO}_{3}{ }^{-}-\mathrm{N}$ is relatively free to move with water flow, it was still the predominant form of TEN across the three treatments (Fig. 3), due to fast mineralization and nitrification in intensively managed agricultural systems (Lentz and Lehrsch, 2012; Zhu et al., 2014). The observed high $\mathrm{NO}_{3}{ }^{-} \mathrm{N}$ concentrations $\left(>200 \mathrm{mg} \cdot \mathrm{kg}^{-1}\right)$ from this study were also founded by other researchers (Fan et al., 2010; Shi et al., 2008). The $\mathrm{NO}_{3}{ }^{-} \mathrm{N}$ accumulation and its temporal variation in the greenhouse soil were probably mediated by the lack of microbial demand in largely aerobic condition, the poor synchronicity of $\mathrm{N}$ decomposition from manures and $\mathrm{N}$ absorption by roots, and $\mathrm{N}$ leaching by irrigation (Zhou et al., 2010).

Besides $\mathrm{NO}_{3}^{-}-\mathrm{N}$, a significant portion of the remaining extractable $\mathrm{N}$ in the soil profile was present as EON. Averaged EON stocks accounted for $18.4 \%$ to $21.5 \%$ of TEN stocks. The EON stock only peaked in the seasons when chicken manure applied (Fig. 3), likely due to the direct input of EON from manures (Goyne et al., 2008) since the chicken manure is rich in EON (Table 2). EON stocks decreased obviously with the enhancement of irrigation in the later periods of vegetable growth. Integrating the findings in grassland, arable, and greenhouse soils (Matlou and Haynes, 2006; Min et al., 2011; Siemens and Kaupenjohann, 2002), the mean percentage of organic $\mathrm{N}$ as total soluble $\mathrm{N}$ in the leachate below rooting zone ranges from $10 \%$ to $38 \%$ (similar to the EON proportion found in this study), highlighting the EON in soils as another important form of $\mathrm{N}$ besides $\mathrm{NO}_{3}{ }^{-}-\mathrm{N}$ subject to leaching loss. The concentrations of $\mathrm{NH}_{4}{ }^{+}-\mathrm{N}$ were relatively low because of its quick transformation (Zhao et al., 2012).

Impact of application of manures. Longterm overuse of manures will lead to $\mathrm{N}$ accumulation in soil since most of organic $\mathrm{N}$ in manure is stable and resistant to quick decomposition (Hati et al., 2008; Lou et al., 2011). The averaged TN accumulation rates in 0 - to $60-\mathrm{cm}$ soil layer were 510 and $726 \mathrm{~kg} \mathrm{~N} / \mathrm{ha} /$ year for M 20 and M 30

Table 3. Nitrogen input ( $\mathrm{kg} \mathrm{N} / \mathrm{ha}$ ) during the 3-year plot experiment from 2011 to 2013.

\begin{tabular}{|c|c|c|c|c|c|c|c|}
\hline \multirow[b]{2}{*}{ Items } & \multicolumn{2}{|c|}{2011} & \multicolumn{2}{|c|}{2012} & \multicolumn{2}{|c|}{2013} & \multirow[b]{2}{*}{ Sum } \\
\hline & Cucumber & Lettuce & Cucumber & Lettuce & Tomato & Lettuce & \\
\hline Compound fertilizer & 150 & 150 & 150 & 150 & 150 & 150 & 900 \\
\hline Chicken manure & $0 / 377 / 565^{z}$ & 0 & $0 / 364 / 547$ & 0 & $0 / 651 / 977$ & 0 & $0 / 1,392 / 2,088$ \\
\hline Cattle manure & 0 & $0 / 288 / 432$ & 0 & $0 / 385 / 577$ & 0 & $0 / 351 / 527$ & $0 / 1,024 / 1,536$ \\
\hline Irrigation & 23 & 7 & 23 & 7 & 23 & 7 & 88 \\
\hline Transplanting & 37 & 8 & 39 & 7 & 21 & 9 & 122 \\
\hline Amino acid fertilizer & 105 & 76 & 105 & 76 & 105 & 76 & 543 \\
\hline Pesticide & $-^{y}$ & - & - & - & - & - & - \\
\hline Dry deposition & - & - & - & - & - & - & - \\
\hline Sum & $358 / 735 / 923$ & $198 / 486 / 630$ & $360 / 724 / 907$ & $197 / 582 / 774$ & $342 / 993 / 1,319$ & $199 / 550 / 726$ & $1,653 / 4,069 / 5,277$ \\
\hline
\end{tabular}

"Nitrogen inputs across the three treatments in the order of "Control/M 20/M 30."

y" __" indicates the input is negligible. 
treatments, respectively (Table 6), higher than that reported by Yan et al. (2012) in similar condition $(210 \mathrm{~kg} \mathrm{TN} / \mathrm{ha} / \mathrm{year}$, in 0 - to $30-\mathrm{cm}$ soil layer). Due to the low density of roots below $20 \mathrm{~cm}$ in shallow-rooted

vegetable production systems, enhanced TEN and TN accumulation in deep soil layers under application of manures would contribute to $\mathrm{N}$ leaching (Fan et al., 2010; Yasuor et al., 2013).

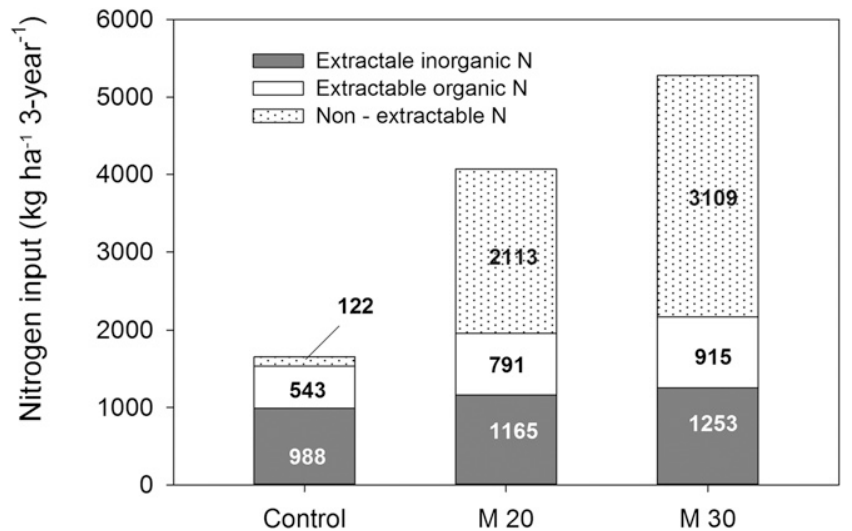

Fig. 2. Partition (water extractable inorganic and organic $\mathrm{N}$, nonextractable $\mathrm{N}$ ) of total $\mathrm{N}$ input during the 3-year experiment. Control: no manure input; M 20: $20 \mathrm{t}$ manure/ha, two-thirds of normal application rate; $\mathrm{M}$ 30: $30 \mathrm{t}$ manure/ha, normal application rate. Extractable inorganic $\mathrm{N}$ (EIN): from compound fertilizer, irrigation, and the EIN part of manures. Extractable organic N (EON): from liquid amino acid fertilizer and the EON part of manures; Nonextractable N (NEN): from transplanting (seedlings, and the soils with seedlings), and the NEN part of manures.

Table 4. Aboveground biomass and biomass $\mathrm{N}$ uptake (mean $\pm \mathrm{SD}, \mathrm{n}=3$ ) during the 3-year plot experiment from 2011 to 2013.

\begin{tabular}{llccccccc}
\hline & & \multicolumn{3}{c}{$\begin{array}{c}\text { Aboveground fresh } \\
\text { biomass }^{\mathrm{z}}\left(\mathrm{t} \cdot \mathrm{ha}^{-1}\right)\end{array}$} & & \multicolumn{3}{c}{ Biomass N uptake $\left(\mathrm{kg} \cdot \mathrm{ha}^{-1}\right)$} \\
\cline { 3 - 5 } \cline { 7 - 8 } Yr & Vegetable & Control & M 20 & M 30 & & Control & M 20 & M 30 \\
\hline 2011 & Cucumber & $211 \pm 23 \mathrm{a}^{\mathrm{y}}$ & $203 \pm 1 \mathrm{a}$ & $192 \pm 19 \mathrm{a}$ & & $394 \pm 33 \mathrm{a}$ & $375 \pm 10 \mathrm{a}$ & $376 \pm 4 \mathrm{a}$ \\
& Lettuce & $57 \pm 3 \mathrm{a}$ & $59 \pm 1 \mathrm{a}$ & $61 \pm 3 \mathrm{a}$ & & $117 \pm 0 \mathrm{a}$ & $114 \pm 16 \mathrm{a}$ & $112 \pm 15 \mathrm{a}$ \\
2012 & Cucumber & $165 \pm 16 \mathrm{~b}$ & $185 \pm 4 \mathrm{a}$ & $194 \pm 3 \mathrm{a}$ & & $283 \pm 26 \mathrm{~b}$ & $325 \pm 15 \mathrm{a}$ & $338 \pm 13 \mathrm{a}$ \\
& Lettuce & $47 \pm 2 \mathrm{~b}$ & $50 \pm 1 \mathrm{ab}$ & $52 \pm 2 \mathrm{a}$ & & $130 \pm 13 \mathrm{a}$ & $149 \pm 3 \mathrm{a}$ & $135 \pm 7 \mathrm{a}$ \\
2013 & Tomato & $204 \pm 11 \mathrm{a}$ & $215 \pm 7 \mathrm{a}$ & $212 \pm 10 \mathrm{a}$ & & $251 \pm 22 \mathrm{a}$ & $273 \pm 18 \mathrm{a}$ & $271 \pm 15 \mathrm{a}$ \\
& Lettuce & $46 \pm 2 \mathrm{~b}$ & $53 \pm 4 \mathrm{a}$ & $58 \pm 2 \mathrm{a}$ & & $84 \pm 20 \mathrm{a}$ & $124 \pm 55 \mathrm{a}$ & $121 \pm 14 \mathrm{a}$ \\
Sum & & $731 \pm 40 \mathrm{a}$ & $766 \pm 11 \mathrm{a}$ & $768 \pm 6 \mathrm{a}$ & & $1,258 \pm 63 \mathrm{a}$ & $1,360 \pm 72 \mathrm{a}$ & $1,353 \pm 30 \mathrm{a}$ \\
\hline
\end{tabular}

${ }^{2}$ Aboveground fresh biomass $=$ fresh fruits + stems + leaves.

y The same lowercase letters behind SD in the same row indicate no significant difference between the two treatments at the 0.05 significance level.
Although application of manures slowed the soil acidification markedly (Fig. 4), the increases in aboveground fresh biomass and biomass $\mathrm{N}$ were not significant in most of vegetable seasons during the 3-year experiment (Table 4), probably due to that the decreased $\mathrm{pH}$ was not harmful enough to impair plant growth in the fertile greenhouse soil. Manures are important sources of salts in greenhouse soil (Shi et al., 2008). Besides $\mathrm{NH}_{4}{ }^{+}$and $\mathrm{NO}_{3}{ }^{-}$, other salts will release during the degradation of the applied animal manures. In this study, after continuous ( 7 years) vegetable cultivation, EC in the surface soil was close to or exceeded the threshold value (1000 $\mu \mathrm{S} \cdot \mathrm{cm}^{-1}$ ) of secondary salinization (Shi et al., 2009).

$N$ balance and $N$ loss. Nitrogen balance is an indirect indicator quantifying $\mathrm{N}$ leaching in agricultural ecosystems (Bosch-Serra et al., 2015). Nitrogen surplus is determined primarily by the input of exogenous $\mathrm{N}$ in relation to the output of $\mathrm{N}$ by crops (Guo et al., 2008; Ren et al., 2010, 2014). Ren et al. (2014) studied the apparent $\mathrm{N}$ balance in a vegetable cultivating greenhouse in Shouguang, northern China, and found as high as $1529 \mathrm{~kg} \mathrm{~N} / \mathrm{ha} /$ year was lost from the system from 2004 to 2010, making up $77 \%$ of the annual $\mathrm{N}$ input. $\mathrm{N}$ accumulation in soil from some studies (Guo et al., 2008; Ren et al., 2014) was calculated as the shift of mineral $\mathrm{N}\left(\Delta \mathrm{N}_{\min }\right)$ during a crop growing season. This might overestimate the $\mathrm{N}$ loss because: 1) applied organic $\mathrm{N}$ and newly synthesized organic $\mathrm{N}$ (vegetable $\operatorname{root} \mathrm{N}$, microbial assimilated $\mathrm{N}$, etc.) in the soil cannot transform to inorganic $\mathrm{N}$ completely; 2) mineral $\mathrm{N}$ in the soil profile has a big temporal variation influenced by water movement and root uptake. Instead, in this study, we used the differences of soil $\mathrm{TN}(\Delta \mathrm{TN})$ as the $\mathrm{N}$ accumulation.

Table 5. Average concentrations (mean $\pm \mathrm{SD}$ ) and percentages of various forms of soil $\mathrm{N}$ during the 3-year vegetables cultivation. Three-way ANOVAs were performed for the individual and interactive effects of treatment (T), depth (D), and sampling period (P), on $\mathrm{NO}_{3}{ }^{-}-\mathrm{N}, \mathrm{NH}_{4}{ }^{+}-\mathrm{N}, \mathrm{EON}$, and TN .

\begin{tabular}{|c|c|c|c|c|c|c|c|c|c|}
\hline Treatment & Layer $(\mathrm{cm})$ & $\begin{array}{c}\mathrm{NO}_{3}{ }^{-} \mathrm{N} \\
\left(\mathrm{mg} \cdot \mathrm{kg}^{-1}\right)\end{array}$ & $\begin{array}{c}\mathrm{NH}_{4}^{+}-\mathrm{N} \\
\left(\mathrm{mg} \cdot \mathrm{kg}^{-1}\right)\end{array}$ & $\begin{array}{c}\text { EON } \\
\left(\mathrm{mg} \cdot \mathrm{kg}^{-1}\right)\end{array}$ & $\begin{array}{c}\mathrm{TN} \\
\left(\mathrm{g} \cdot \mathrm{kg}^{-1}\right)\end{array}$ & $\begin{array}{c}\mathrm{NO}_{3}{ }^{-} \mathrm{N} / \mathrm{TEN} \\
(\%)\end{array}$ & $\begin{array}{c}\mathrm{NH}_{4}{ }^{+}-\mathrm{N} / \mathrm{TEN} \\
(\%)\end{array}$ & $\begin{array}{c}\text { EON/TEN } \\
(\%)\end{array}$ & $\begin{array}{c}\text { TEN/TN } \\
(\%)\end{array}$ \\
\hline \multirow[t]{3}{*}{ Control } & $0-10$ & $73.4 \pm 43.8$ & $6.4 \pm 7.2$ & $11.4 \pm 6.1$ & $1.11 \pm 0.10$ & 80.5 & 7.0 & 12.5 & 8.2 \\
\hline & $10-20$ & $38.1 \pm 21.3$ & $4.2 \pm 6.1$ & $9.0 \pm 5.0$ & $0.89 \pm 0.06$ & 74.3 & 8.2 & 17.5 & 5.8 \\
\hline & $40-60$ & $14.7 \pm 6.5$ & $2.3 \pm 3.5$ & $7.6 \pm 3.8$ & $0.54 \pm 0.04$ & 59.8 & 9.3 & 30.9 & 4.6 \\
\hline \multirow[t]{2}{*}{ M 20} & $0-10$ & $98.5 \pm 68.3$ & $5.4 \pm 6.3$ & $16.6 \pm 10.7$ & $1.42 \pm 0.19$ & 81.7 & 4.5 & 13.8 & 8.5 \\
\hline & $10-20$ & $53.2 \pm 33.6$ & $3.6 \pm 3.3$ & $10.6 \pm 5.2$ & $1.13 \pm 0.09$ & 78.9 & 5.4 & 15.7 & 6.0 \\
\hline \multirow[t]{4}{*}{ M 30} & $0-10$ & $146.1 \pm 79.6$ & $6.3 \pm 8.3$ & $25.3 \pm 21.8$ & $1.68 \pm 0.31$ & 82.2 & 3.6 & 14.2 & 10.6 \\
\hline & $10-20$ & $65.1 \pm 30.5$ & $4.1 \pm 5.5$ & $15.8 \pm 13.4$ & $1.14 \pm 0.22$ & 76.6 & 4.8 & 18.6 & 7.5 \\
\hline & $20-40$ & $35.7 \pm 16.8$ & $3.1 \pm 3.6$ & $10.4 \pm 6.8$ & $0.71 \pm 0.06$ & 72.6 & 6.3 & 21.1 & 6.9 \\
\hline & $40-60$ & $32.8 \pm 18.0$ & $3.7 \pm 4.3$ & $10.1 \pm 5.6$ & $0.56 \pm 0.06$ & 70.4 & 7.9 & 21.7 & 8.3 \\
\hline
\end{tabular}

Three-way ANOVAs

$\mathrm{T}$
$\mathrm{D}$
$\mathrm{P}$
$\mathrm{T} \times \mathrm{D}$
$\mathrm{T} \times \mathrm{P}$
$\mathrm{D} \times \mathrm{P}$
$\mathrm{T} \times \mathrm{P} \times \mathrm{D}$

$58.1^{* *}$
$206.4^{* *}$
$74.2^{* *}$
$9.4^{* *}$
$6.3^{* *}$
$12.4^{* *}$
1.2

\begin{tabular}{lrr}
\multicolumn{2}{c}{ F values } & \\
0.8 & $20.5^{* *}$ & $116.3^{* *}$ \\
$3.9^{* *}$ & $34.6^{* *}$ & $894.4^{* *}$ \\
$3.8^{*}$ & $23.8^{* *}$ & $24.2^{* *}$ \\
0.7 & $5.8^{* *}$ & $32.6^{* *}$ \\
1.3 & $11.5^{* *}$ & $11.3^{* *}$ \\
0.6 & $3.3^{* *}$ & $4.8^{* *}$ \\
0.6 & 1.3 & $2.4^{* *}$
\end{tabular}

**, *Significant at a significance level of $1 \%$ and $5 \%$ probability, respectively. 


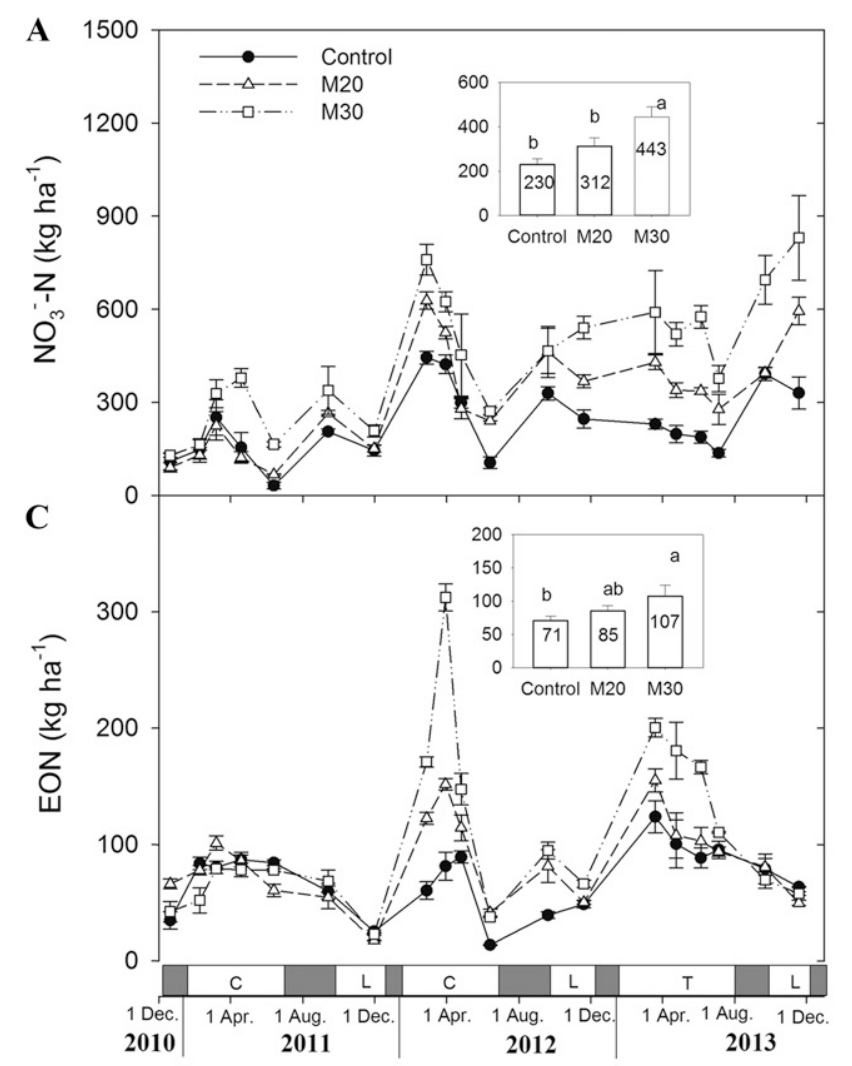

Sampling time

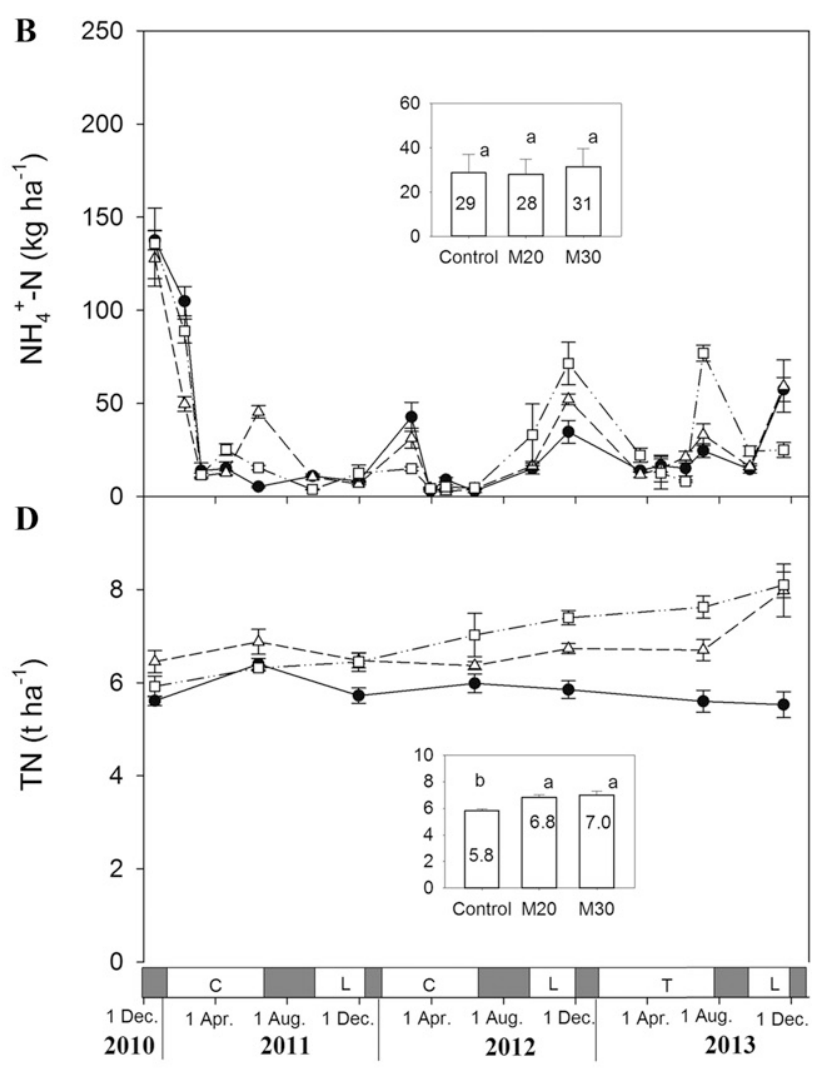

Sampling time

Fig. 3. Soil nitrate $\left(\mathrm{NO}_{3}{ }^{-}-\mathrm{N}\right)$, ammonium $\left(\mathrm{NH}_{4}{ }^{-}-\mathrm{N}\right)$, extractable organic $\mathrm{N}(\mathrm{EON})$, and total $\mathrm{N}(\mathrm{TN})$ stocks dynamics in 0 - to 60 -cm soil profile affected by application of manures during the 3-year vegetables cultivation in greenhouse. Control: no manure input; M 20: 20 t manure/ha, two-thirds of normal application rate; M 30: $30 \mathrm{t}$ manure/ha, normal application rate. Small histograms inside line charts are the averaged stocks during the 3-year experiment.

Table 6. Apparent $\mathrm{N}$ balance between $\mathrm{N}$ input and output together with $\mathrm{N}$ loss $(0-60 \mathrm{~cm}, \mathrm{~kg} \mathrm{~N} / 3$ year $)$ at the end of the 3-year vegetables cultivation in greenhouse.

\begin{tabular}{lccccccc}
\hline Treatments & $\mathrm{N} \mathrm{input}^{\mathrm{z}}$ & $\mathrm{N}$ uptake $^{\mathrm{y}}$ & ${\text { Soil } \Delta \mathrm{TN}^{\mathrm{x}}}$ & $\mathrm{N} \mathrm{loss}^{\mathrm{w}}$ & $\begin{array}{c}\mathrm{N} \text { uptake/N } \\
\text { input }(\%)\end{array}$ & $\begin{array}{c}\text { Soil } \Delta \mathrm{TN} / \mathrm{N} \\
\text { input }\end{array}$ & $\begin{array}{c}\mathrm{N} \text { loss/N } \\
\text { input }(\%)\end{array}$ \\
\hline Control & 1,653 & $1,258 \mathrm{a}$ & $-82 \mathrm{~b}$ & $477 \mathrm{~b}$ & $76.1 \mathrm{a}$ & $-4.9 \mathrm{~b}$ & $28.9 \mathrm{a}$ \\
M 20 & 4,069 & $1,360 \mathrm{a}$ & $1,529 \mathrm{a}$ & $1,180 \mathrm{a}$ & $33.4 \mathrm{~b}$ & $37.6 \mathrm{a}$ & $29.0 \mathrm{a}$ \\
M 30 & 5,277 & $1,353 \mathrm{a}$ & $2,177 \mathrm{a}$ & $1,747 \mathrm{a}$ & $25.6 \mathrm{c}$ & $41.2 \mathrm{a}$ & $33.1 \mathrm{a}$ \\
\hline
\end{tabular}

${ }^{\mathrm{z}}$ Input [total $\mathrm{N}(\mathrm{TN})$ input, including all the $\mathrm{N}$ sources]: see Table 3.

${ }^{y} \mathrm{~N}$ uptake (aboveground biomass $\mathrm{N}$ uptake, including fruits, stems, and leaves): see Table 4.

${ }^{\mathrm{x}}$ Soil $\triangle \mathrm{TN}$ : difference in $\mathrm{TN}$ stocks between the periods just before the start and at the end of the 3-year experiment.

${ }^{\mathrm{w}} \mathrm{N}$ loss $=\mathrm{N}$ input $-\mathrm{N}$ uptake - soil $\Delta \mathrm{TN}$. The same lowercase letters behind sD in the same volume indicate no significant difference between the two treatments at the 0.05 significance level.

When calculating the $\mathrm{N}$ balance in this study, the runoff $\mathrm{N}$ loss could be ignored due to strict control of surface runoff in greenhouse. The $\mathrm{NH}_{3}$ volatilization was assumed to be low when the soil $\mathrm{pH}<7.0$ $(<1 \mathrm{~kg} \mathrm{~N} / \mathrm{ha} /$ season, reported in Min et al., 2011 in similar condition). And the denitrification loss (e.g., $\mathrm{N}_{2} \mathrm{O}, \mathrm{N}_{2}$ emission) was also assumed to be relatively weak as the good permeability of soils and little available $\mathrm{C}$ to fuel denitrification according to others' studies in intensively managed greenhouse vegetable systems $\left(2.6-8.8 \mathrm{~kg} \mathrm{~N} \mathrm{~N}_{2} \mathrm{O}-\mathrm{N} / \mathrm{ha} /\right.$ year, $0.24 \%$ to $0.30 \%$ of N input, Diao et al., 2013; $\mathrm{He}$ et al., 2009). The annual $\mathrm{N}$ loss rates during the 3-year vegetables cultivation in greenhouse were averaged at 159,393 , and $582 \mathrm{~kg} \cdot \mathrm{ha}^{-1}$ per year for Control, M 20, and M 30 treatments, respectively (Table 6). The sum of gaseous $\mathrm{N}$ losses via volatilization and denitrification should be small compared with the annual $\mathrm{N}$ loss in the 0 to $60-\mathrm{cm}$ soil profile of each treatment, implying that leaching should be largely responsible for $\mathrm{N}$ loss out of 0 - to $60-\mathrm{cm}$ soil profile under the condition of high irrigation.

Constant monoculture, excessive fertilization, and irrigation, and high-intensity anthropogenic interference had led to high accumulation of $\mathrm{N}$ and possible leaching loss in intensively managed greenhouse systems. How to balance crop yield, soil acidification, soil salinization, and the leaching of nitrate-dominated mobile $\mathrm{N}$ is a challenge (Yasuor et al., 2013). Zhao et al. (2012) suggested adding dairy manure to regulate soil $\mathrm{C}: \mathrm{N}$ ratio could be an appropriate fertilization practice for reducing soil $\mathrm{N}$ leaching. However, our study showed that enhanced accumulation of mobile $\mathrm{N}$ induced by excessive manure input could exceed the need of plant uptake but subject to downward migration and leaching-dominated loss. More attention should be paid to prevent the manureinduced dilemma in high-input agricultural ecosystems by using best management practices, especially balancing fertilization, as well as providing practical advice to farmers to alleviate the overuse and misuse of manures.

\section{Conclusions}

Application of manures slowed acidification but accelerated salinization of the fertile greenhouse soil, and did not significantly enhance the aboveground fresh biomass and biomass $\mathrm{N}$ in most of vegetable seasons during the 3-year experiment. High-rate application of manures resulted in high accumulation of not only nonextractable $\mathrm{N}$ but also leachable $\mathrm{N}$ including nitrate and EON, consequently intensifying leaching-dominated $\mathrm{N}$ loss. The role of manures played in high-input agricultural ecosystems needs to be re-examined to well 
$\mathbf{A}$

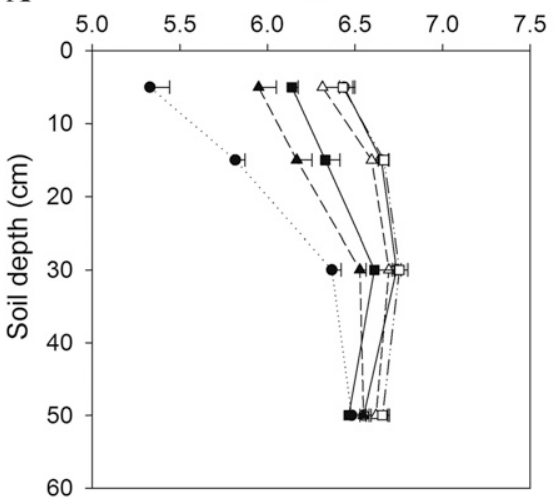

B

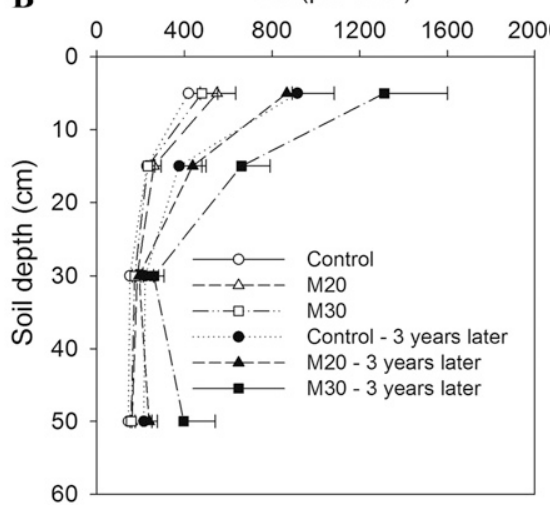

Fig. 4. Changes of $\mathrm{pH}$ and $\mathrm{EC}$ in 0 - to 60 -cm soil profile after 3-year application of manures and vegetables cultivation in greenhouse. Control: no manure input; M 20: 20 t manure/ha, two-thirds of normal application rate; M 30: $30 \mathrm{t}$ manure/ha, normal application rate.

balance its economical benefit for crop growth and its environmental risk of enhancing $\mathrm{N}$ loss.

\section{Literature Cited}

Bergström, L. and H. Kirchmann. 1999. Leaching of total nitrogen from nitrogen-15-labeled poultry manure and inorganic nitrogen fertilizer. J. Environ. Qual. 28:1283-1290.

Bhogal, A., D.V. Murphy, S. Fortune, M.A. Shepherd, D.J. Hatch, S.C. Jarvis, J.L. Gaunt, and K.W.T. Goulding. 2000. Distribution of nitrogen pools in the soil profile of undisturbed and reseeded grasslands. Biol. Fertil. Soils 30:356-362.

Bosch-Serra, A., D.C. Ortiz, M.R. Yagüe, and J. Boixadera. 2015. Strategies to optimize nitrogen efficiency when fertilizing with pig slurries in dryland agricultural systems. Eur. J. Agron. 67:27-36.

Diao, T., L. Xie, L. Guo, H. Yan, M. Lin, H. Zhang, J. Lin, and E. Lin. 2013. Measurements of $\mathrm{N}_{2} \mathrm{O}$ emissions from different vegetable fields on the North China Plain. Atmos. Environ. 72:70-76.

Fan, J., M. Hao, and S.S. Malhi. 2010. Accumulation of nitrate-N in the soil profile and its implications for the environment under dryland agriculture in northern China: A review. Can. J. Soil Sci. 90:429-440.

Gao, J., X. Bai, B. Zhou, J. Zhou, and Z. Chen. 2012. Soil nutrient content and nutrient balances in newly-built solar greenhouses in northern China. Nutr. Cycl. Agroecosyst. 94:63-72.

Goyne, K.W., H.J. Jun, S.H. Anderson, and P.P. Motavalli. 2008. Phosphorus and nitrogen sorption to soils in the presence of poultry litterderived dissolved organic matter. J. Environ. Qual. 37:154-163.

Guo, R., X. Li, P. Christie, Q. Chen, R. Jiang, and F. Zhang. 2008. Influence of root zone nitrogen management and a summer catch crop on cucumber yield and soil mineral nitrogen dynamics in intensive production systems. Plant Soil 313:55-70.

Hati, K.M., A. Swarup, B. Mishra, M.C. Manna, R.H. Wanjari, K.G. Mandal, and A.K. Misra. 2008. Impact of long-term application of fertilizer, manure and lime under intensive cropping on physical properties and organic carbon content of an Alfisol. Geoderma 148:173-179.

He, F., R. Jiang, Q. Chen, F. Zhang, and F. Su. 2009. Nitrous oxide emissions from an intensively managed greenhouse vegetable cropping system in Northern China. Environ. Pollut. 157:1666-1672.
Ju, X., C. Kou, P. Christie, Z. Dou, and F. Zhang 2007. Changes in the soil environment from excessive application of fertilizers and manures to two contrasting intensive cropping systems on the North China Plain. Environ. Pollut. 145:497-506.

Ju, X., C. Kou, F. Zhang, and P. Christie. 2006. Nitrogen balance and groundwater nitrate contamination: Comparison among three intensive cropping systems on the North China Plain. Environ. Pollut. 143:117-125.

Khalili, B. and F. Nourbakhsh. 2012. Vertical distribution of soluble organic nitrogen, nitrogen mineralization, nitrification, and amidohydrolase activities in a manure-treated soil. J. Plant Nutr. Soil Sci. 175:265-272.

Lei, B., M. Fan, Q. Chen, J. Six, and F. Zhang. 2010. Conversion of wheat-maize to vegetable cropping systems changes soil organic matter characteristics. Soil Sci. Soc. Amer. J. 74:1320-1326.

Lentz, R.D. and G.A. Lehrsch. 2012. Net nitrogen mineralization from past years' manure and fertilizer applications. Soil Sci. Soc. Amer. J. 76:1005.

Lou, Y., M. Xu, W. Wang, X. Sun, and C. Liang. 2011. Soil organic carbon fractions and management index after $20 \mathrm{yr}$ of manure and fertilizer application for greenhouse vegetables. Soil Use Mgt. 27:163-169.

Matlou, M.C. and R.J. Haynes. 2006. Soluble organic matter and microbial biomass $\mathrm{C}$ and $\mathrm{N}$ in soils under pasture and arable management and the leaching of organic $\mathrm{C}, \mathrm{N}$ and nitrate in a lysimeter study. Appl. Soil Ecol. 34:160-167.

Min, J., X. Zhao, W. Shi, G. Xing, and Z. Zhu. 2011. Nitrogen balance and loss in a greenhouse vegetable system in Southeastern China. Pedosphere 21:464-472.

Qiu, S., X. Ju, J. Ingwersen, Z. Qin, L. Li, T. Streck, P. Christie, and F. Zhang. 2010. Changes in soil carbon and nitrogen pools after shifting from conventional cereal to greenhouse vegetable production. Soil Tillage Res. 107:80-87.

Quan, Z., C. Lu, Y. Shi, X. Chen, B. Huang, Y. Wang, Y. Zhao, and J. Ma. 2014. Manure increase the leaching risk of soil extractable organic nitrogen in intensively irrigated greenhouse vegetable cropping systems. Acta Agr. Scand. Sect. B-Soil Pl. 65:199-207.

Ren, T., P. Christie, J. Wang, Q. Chen, and F. Zhang. 2010. Root zone soil nitrogen management to maintain high tomato yields and minimum nitrogen losses to the environment. Sci. Hort. 125:25-33.

Ren, T., J. Wang, Q. Chen, F. Zhang, and S. Lu. 2014. The effects of manure and nitrogen fertilizer applications on soil organic carbon and nitrogen in a high-Input cropping system. PLoS One 9:e97732.

Shen, W., X. Lin, W. Shi, J. Min, N. Gao, H. Zhang, R. Yin, and X. He. 2010. Higher rates of nitrogen fertilization decrease soil enzyme activities, microbial functional diversity and nitrification capacity in a Chinese polytunnel greenhouse vegetable land. Plant Soil 337:137-150.

Shi, W., J. Yao, and F. Yan. 2008. Vegetable cultivation under greenhouse conditions leads to rapid accumulation of nutrients, acidification and salinity of soils and groundwater contamination in South-Eastern China. Nutr. Cycl. Agroecosyst. 83:73-84.

Shi, Y., Z. Hu, S. Haneklaus, W. Long, X. Xia, Y. Zhao, T. Lin, and E. Schnug. 2009. Suitability of soil electrical conductivity as an indicator of soil nitrate status in relation to vegetable cultivation practices in the Yangtze River Delta of China. Landbauforschung Volk. 59:151-158.

Siemens, J. and M. Kaupenjohann. 2002. Contribution of dissolved organic nitrogen to $\mathrm{N}$ leaching from four German agricultural soils. J. Plant Nutr. Soil Sci. 165:675-681.

Thompson, R.B., C. Martínez-Gaitan, M. Gallardo, C. Giménez, and M.D. Fernández. 2007. Identification of irrigation and $\mathrm{N}$ management practices that contribute to nitrate leaching loss from an intensive vegetable production system by use of a comprehensive survey. Agr. Water Mgt. 89:261-274.

Tian, Y., J. Liu, X. Wang, and L. Gao. 2011. Carbon mineralization in the soils under different cover crops and residue management in an intensive protected vegetable cultivation. Sci. Hort. 127:198-206.

Yan, Y., J. Tian, M. Fan, F. Zhang, X. Li, P. Christie, H. Chen, J. Lee, Y. Kuzyakov, and J. Six. 2012. Soil organic carbon and total nitrogen in intensively managed arable soils. Agr. Ecosyst. Environ. 150:102-110.

Yasuor, H., A. Bengal, U. Yermiyahu, E. Beityannai, and S. Cohen. 2013. Nitrogen management of greenhouse pepper production: Agronomic, nutritional, and environmental implications. HortScience 48:1241-1249.

Zhang, L., X. Ju, C. Liu, and C. Kou. 2010. A study on nitrate contamination of groundwater sources in areas of protected vegetables growing fields - a case study in Huimin county, Shandong province. Sci. Agr. Sin. 43:4427-4436.

Zhao, S., S. Qiu, C. Cao, C. Zheng, W. Zhou, and P. He. 2014. Responses of soil properties, microbial community and crop yields to various rates of nitrogen fertilization in a wheat-maize cropping system in north-central China. Agr. Ecosyst. Environ. 194:29-37.

Zhao, Y., J. Luo, X. Chen, X. Zhang, and W. Zhang. 2012. Greenhouse tomato-cucumber yield and soil $\mathrm{N}$ leaching as affected by reducing $\mathrm{N}$ rate and adding manure: A case study in the Yellow River Irrigation Region China. Nutr. Cycl. Agroecosyst. 94:221-235.

Zhou, J., Z. Chen, X. Liu, B. Zhai, and D.S. Powlson. 2010. Nitrate accumulation in soil profiles under seasonally open 'sunlight greenhouses' in northwest China and potential for leaching loss during summer fallow. Soil Use Mgt. 26:332-339.

Zhu, T., Q. Dang, J. Zhang, C. Müller, and Z. Cai. 2014. Reductive soil disinfestation (RSD) alters gross $\mathrm{N}$ transformation rates and reduces $\mathrm{NO}$ and $\mathrm{N}_{2} \mathrm{O}$ emissions in degraded vegetable soils. Plant Soil 382:269-280.

Zhu, Z. and D. Chen. 2002. Nitrogen fertilizer use in China-Contributions to food production, impacts on the environment and best management strategies. Nutr. Cycl. Agroecosyst. 63:117-127. 